\title{
PENGARUH STATUS SOSIAL EKONOMI ORANG TUA, MOTIVASI BELAJAR, DISIPLIN BELAJAR TERHADAP PRESTASI BELAJAR PADA SISWA SMK BARUNAWATI SURABAYA
}

\author{
Atya Rizkiana, SMK Barunawati Surabaya \\ ratya.rizki@gmail.com
}

\begin{abstract}
ABSTRAK
Penelitian ini bertujuan untuk menentukan pengaruh status sosial ekonomi, motivasi belajar, disiplin belajar terhadap prestasi belajar di SMK Barunawati Surabaya. Penelitian kuantitatif ini menggunakan metode deskriptif. Populasi dalam penelitian ini merupakan siswa kelas X di SMK Barunawati Surabaya yang terdiri dari 103 siswa. Sampelnya 82 siswa, yang dipilih menggunakan teknik proporsional random sampling. Analisis data menggunakan analisis regresi berganda. Hasilnya menunjukkan terdapat pengaruh yang signifikan secara parsial antara status sosial ekonomi orang tua, motivasi belajar, dan disiplin belajar terhadap prestasi belajar. Terdapat pengaruh signifikan secara simultan antara status sosial ekonomi orang tua, motivasi belajar, dan disiplin belajar terhadap prestasi belajar.
\end{abstract}

Kata kunci: Status Sosial Ekonomi, Motivasi Belajar, Disiplin Belajar, Prestasi Belajar.

\section{ABSTRACT}

The purpose of this study was to determine the effect of socioeconomic status, learning motivation, and learning disipline on student achievement at SMK Barunawati Surabaya. This study quantitative methods as a research methodology descriptive design. Population in this study are tenth grades students in SMK Barunawati Surabaya who are 103 students. Sampel was 82 students, selected by using Proporsional Random Sampling. Data analysed using multiple regression analysis. The result showed that socioeconomic status, learning motivation and learning discipline has partially significant impact on student achievement. Socioeconomic status, learning motivation and learning discipline have a significant impact on student achievement.

Keywords: Socioeconomic Status, Learning Motivation, and Learning Discipline on Student Achievement.

\section{PENDAHULUAN}

Pendidikan biasanya berawal saat seorang bayi itu dilahirkan dan berlangsung seumur hidup. Pendidikan bisa saja berawal dari sebelum bayi lahir seperti yang dilakukan oleh banyak orang dengan memainkan musik dan membaca kepada bayi dalam kandungan dengan harapan ia bisa mengajar bayi mereka sebelum kelahiran. Bagi sebagian orang, pengalaman kehidupan seharihari lebih berarti daripada pendidikan formal. Meskipun secara tidak langsung pengalaman yang didapat meskipun tidak melalui bangku sekolah itu dapat disebut dengan ilmu yang merupakan hasil dari pendidikan. Ungkapan diatas sesuai dengan pengertian pendidikan menurut Mujiono (2007) dimana pendidikan 
adalah sesuatu tindakan yang memungkinkan terjadinya belajar dan perkembangan.

Pendidikan juga dapat mengandung pengertian mendidik, membimbing, mengajar dan melatih yang tertuang dalam proses pendidikan di sekolah. Sekolah sebagai lembaga pendidikan formal merupakan sarana dalam rangka pencapaian tujuan pendidikan melalui proses belajar mengajar. Dengan belajar peserta didik dapat menunjukkan adanya perubahan sikapnya positif sehingga pada tahap akhir akan mendapatkan ketrampilan, kecakapan dan pengetahuan baru. Dalam mengikuti proses belajar mengajar tentu seseorang akan mengharapkan akan memperoleh hasil yang bagus.

Dalam proses belajar mengajar yang baik hasil yang dimaksud adalah prestasi belajar. Menurut Azwar (2003) menyatakan prestasi belajar sebagai suatu keberhasilan memperoleh pengetahuan dan kecakapan baru yang dapat di operasionalkan dalam bentuk indikator-indikator berupa nilai rapor, indeks prestasi pendidikan, angka kelulusan, predikat keberhasilan dan semacamnya. Prestasi belajar siswa dipengaruhi oleh beberapa faktor yaitu antara lain: sikap belajar, motivasi, disiplin, lingkungan keluarga dll. Menurut Tjundjing (2001: 71) menyatakan bahwa prestasi belajar adalah suatu istilah yang menunjukkan tingkat penguasaan peserta didik terhadap bahan pelajaran yang diajarkan yang diikuti oleh munculnya perasaan puas bahwa ia telah melakukan sesuatu dengan baik.

Prestasi belajar bisa dilihat salah satunya dengan melihat dari nilai rapor siswa pada setiap akhir semester. Untuk kategori Sekolah Menengah Kejuruan (SMK) terdapat beberapa mata pelajaran kejuruan yang disesuaikan dengan jurusan yang mereka ambil. Selain nilai yang berupaka angka dalam rapor juga tertulis nilai yang berupa huruf (predikat). Untuk beberapa pelajaran normatif dan adaptif (diluar mata pelajaran kejuruan) nilai huruf (predikat) biasanya berupa nilai A untuk Amat Baik, B untuk Baik, C untuk Cukup, dan K untuk kurang.

Berbeda dengan kategori penilaian huruf atau predikat untuk mata pelajaran produktif atau mata pelajaran kejuruan dimana hanya terdiri dari dua keterangan saja yaitu $\mathrm{K}$ untuk Kompeten dan BK untuk Belum Kompeten. Dikatakan Kompeten jika nilai yang siswa dapat sudah mencapai atau melampaui nilai KKM (Kriteria Ketuntasan Minimal). Untuk beberapa mata pelajaran produktif atau kejuruan nilai KKM (Kriteria Ketuntasan Minimal) rata-rata nilai yang harus dicapai adalah 80 sedangkan untuk adaptif dan normatif rata-rata nilai yang harus dicapai adalah 75. Kenyataannya berdasarkan dokumentasi peneliti nilai rata-rata ssiswa X Apk 1 sampai X Apk 3 hanya berkisar 84-86 dengan nilai KKM (Kriteria Ketuntasan Minimal) untuk nilai mata pelajaran produktif 80.

Status sosial ekonomi juga berhubungan dengan kemampuan orang tua dalam hal memberikan motivasi sesuai dengan latar pendidikan mereka, pendapatan orang tua dan pekerjaan yang mempengaruhi orang tua memberikan motivasi belajar untuk anak-anaknya. Status sosial ekonomi menurut Saifi (2011:119) status sosial ekonomi orang tua terdiri dari pendidikan, pekerjaan, pendapatan orang tua, material yang dimiliki, pelayanan, dan sarana transportasi.

Dari data yang diperoleh dari Bimbingan Konseling di SMK Barunawati Surabaya jenis latar belakang pekerjaan orang tua siswa jurusan administrasi perkantoran di kelas $\mathrm{X}$ (sepuluh) dapat dilihat, orangtua sebagai pegawai negeri sipil sebanyak $4,8 \%$, pegawai swasta sebanyak $50 \%$, pedagang sebanyak $20,2 \%$ sedangkan sebagai buruh dan pekerjaan lain-lain masing-masing 12,5\%. Kategori 
dan lain-lain ini terdiri dari pensiunan, ibu rumah tangga dan orang tua siswa yang tidak mampu.

Sedangkan untuk tingkat pendapatan, orang tua siswa yang termasuk dalam kategori pendapatan sangat tinggi sebanyak $6,7 \%$, pendapatan tinggi sebanyak $10,6 \%$, dan kategori pendapatan sebanyak $57,7 \%$ dan pendapatan rendah sebanyak $25 \%$. Maka dapat disimpulkan jika sebagian besar pendapatan orang tua siswa terutama di jurusan administrasi perkantoran ini berada pada kategori berpendapatan sedang dengan rentang pendapatan $\geq \mathrm{Rp}$. 1.500.000,00 $-\leq \mathrm{Rp}$. 2.500.000,00 per bulan. Dengan pendapatan yang berada pada kategori pendapatan sedang ini keluarga harus mengelola pendapatannya untuk mencukupi kebutuhan hidup dan mencukupi kebutuhan pendidikan anak-anak mereka.

Sedangkan motif sekunder menurut Schunk (2012: 386) berhubungan erat dengan konsep pembelajaran, dimana prinsip pembelajaran dari penguatan (reinforcement) secara konseptual dan praktis berhubungan dengan motivasi. Beberapa diskusi menganggap penguatan hanya sebagai konsekuensi yang berfungsi meningkatkan motivasi untuk kembali menunjukkan perilaku dalam sebuah organisasi.

Di SMK Barunawati Surabaya motivasi belajar ditunjukkan dengan dukungan dari sekolah berupa lingkungan belajar kondusif yang memungkinkan siswa untuk belajar lebih giat lagi. Hal ini ditunjukkan dengan melengkapi kegiatan belajar mengajar dengan laboratorium komputer terutama untuk mata pelajaran Mengoperasikan Aplikasi Presentasi dan Mengoperasikan Aplikasi Perangkat Lunak. Dari data yang diperoleh dapat dijelaskan jika sekolah yaitu SMK Barunawati Surabaya mendukung kegiatan belajar mengajar siswa siswinya dengan melengkapi sarana prasarana disekolah terutama beberapa pelajaran produktif yang kegiatannya berhubungan langsung dengan penggunaan peralatan kantor. Di setiap ruang kelas pun dilengkapi dengan LCD dan Layar LCD guna mendukung kegiatan belajar mengajar terutama pelajaran Mengoperasikan Aplikasi Presentasi yang digunakan siswa untuk mempresentasikan hasil belajarnya yang berupa tampilan power point.

Dukungan lain yang membangun motivasi belajar siswa adalah dengan disiplin belajar. Berdasarkan teori Setyowati (dalam Tomo, 2008: 47) menyatakan belajar harus disiplin, karena disiplin adalah kunci sukses. Diungkapkan pula untuk mencapai prestasi belajar maksimal diperlukan sikap mental siswa dalam mengarahkan seluruh kegiatan belajarnya. Siswa yang ingin prestasi belajarnya tinggi harus mempunyai disiplin belajar yang tinggi. Hal ini disebabkan karena disiplin yang tinggi membuat siswa senantiasa mempunyai kesediaan, kegairahan dan tanggung jawab dalam belajar.

Salah satu cara untuk menilai kedisiplinan siswa di sekolah yaitu dapat di lihat dari intensitas keterlambatan siswa. Setiap kali terdapat siswa yang terlambat masuk ke sekolah guru BK (Bimbingan Konseling) tidak mengijinkan siswa masuk tanpa membawa surat ijin terlambat yang akan diberikan pada guru yang sedang mengajar dikelasnya. Jika keterlambatan lebih dari 15 (lima belas) menit, maka siswa tidak diijinkan untuk mengikuti pelajaran selama 1 (satu) jam pelajaran. Siswa tersebut selama menunggu satu jam pelajaran diberikan nasehat dan didata oleh BK (Bimbingan Konseling) agar tidak terlambat kembali dan diberikan hukuman untuk memersihkan lingkungan sekolah. 
Data keterlambatan siswa terutama siswa kelas X (sepuluh) Administrasi Perkantoran tahun ajaran 2013 - 2014. Berdasarkan data di sekolah untuk kelas X APK 1 siswa yang terlambat berjumlah 5 orang atau 13\%, kelas X APK 2 sebanyak 6 orang atau 16\%, dan untuk siswa kelas X APK3 sebanyak 5 orang atau sekitar $17 \%$ yang terlambat datang ke sekolah selama bulan Maret.

Dalam penelitian Syamsuddin (2002) menyatakan jika disiplin belajar berhubungan dengan positif dengan prestasi siswa SLTP Negeri di Kabupaten Malang. Dalam penelitian Widodo (2007) dimana hasil penelitiannya menunjukkan bahwa prestasi belajar dipengaruhi oleh variabel motivasi belajar, hasil prakerin, dan latar belakang keluarga siswa sebagai variabel bebas. Dan ketiga variabel tersebut berpengaruh signifikan terhadap prestasi belajar. Variabel motivasi belajar berpengaruh sebesar $22,5 \%$ terhadap prestasi belajar. Sedangkan penelitian Tomo (2008) hasil penelitiannya menunjukkan jika antara sikap, motivasi dan disiplin belajar dan prestasi belajar mempunyai hubungan yang signifikan baik secara parsial maupun secara simultan.

Dari kedua penelitian diatas terdapat dua variabel yang sama dimana variabel motivasi belajar mempengaruhi prestasi belajar siswa. Sedangkan variabel pendukung lainnya seperti hasil prakerin, latar belakang siswa, sikap dan disiplin belajar merupakan variabel bebas didalam dua penelitian tersebut yang mempunyai pengaruh atau berhubungan secara parsial maupun secara simultan terhadap prestasi belajar siswa. Ditambah dengan penelitian yang dilakukan oleh Syamsuddin (2002) dimana hasil penelitian menunjukkan jika disiplin belajar dan motivasi belajar berhubungan positif dengan prestasi belajar siswa.

Selain hubungan yang signifikan positif terdapat pula penelitian yang dilakukan oleh Ogunshola (2012) "it can be reasonably that socio-economic and education background of parents in this research is not significant factors in students academic performance. however educational qualification of parents and health status of students are significant factors that affect the academic performance of students". Dimana ini menjelaskan jika sosio ekonomi dan latar belakang pendidikan orang tua tidak berpengaruh terhadap prestasi belajar.

Terdapat pula penelitian dari Cahyono (2013) status sosial ekonomi merupakan kedudukan seseorang di dalam lingkungan kelompok masyarakat berdasarkan penagkuan social, dan kemampuan memenuhi kebutuhan. Dimana nantinya latar belakang berhubungan dengan status pekerjaannya dan kontribusi pada tinggi/rendahnya penghasilan yang akan diperoleh.

Dari dua penelitian diatas yang dilakukan oleh Widodo (2007) yang menyatakan jika latar belakang keluarga berpengaruh signifikan positif terhadap prestasi. Sedangkan dalam penelitian Ogunshola (2012) menjelaskan jika tidak terdapat pengaruh yang signifikan antara latar belakang pendidikan orang tua dan sosio ekonomi terhadap prestasi belajar.

Dengan demikian, tujuan penelitian ini diantaranya: (1) Menganalisis bagaimana pengaruh secara parsial antara status sosial ekonomi orang tua, motivasi belajar, dan disiplin belajar terhadap prestasi belajar. (2) Menganalisis bagaimana pengaruh secara simultan antara status sosial ekonomi orang tua, motivasi belajar, dan disiplin belajar terhadap prestasi belajar. 


\section{METODE PENELITIAN}

Jenis penelitian yang akan dipakai peneliti yaitu jenis penelitian kuantitatif. Sedangkan penelitian ini menggunakan metode deskriptif. Penelitian ini menggunakan empat macam variabel yang terdiri dari tiga variabel independent (variabel bebas) dan satu variabel dependent (variabel terikat). Yang menjadi variabel bebas dalam penelitian ini adalah status sosial ekonomi $\left(\mathrm{X}_{1}\right)$, motivasi belajar $\left(\mathrm{X}_{2}\right)$, disiplin belajar $\left(\mathrm{X}_{3}\right)$. Sedangkan yang menjadi variabel terikat dalam penelitian ini adalah prestasi belajar (Y). Jumlah keseluruhan populasi adalah 103 siswa yang telah lulus mata pelajaran produktif atau kejuruan mengoperasikan aplikasi presentasi dan mengoperasikan aplikasi perangkat lunak. Sampel yang digunakan sebanyak 82 siswa dan teknik pengambilan sampelnya proporsional random sampling.

Teknik pengumpulan data dalam penelitian ini digunakan dengan berbagai cara dokumentasi dan angket. Dokumentasi untuk mengumpulkan data dari sebagian variabel status sosial ekonomi dan prestasi belajar, sedangkan angket untuk mengumpulkan data dari variabel status sosial ekonomi, motivasi belajar, dan disiplin belajar. Angket menggunakan 3 skala yaitu skala nominal, skala ordinal, dan skala guttman. Adapun daftar nilai rapor digunakan untuk mengukur prestasi belajar. Teknik analisa data yang dgunakan adalah regresi ganda dengan menggunakan rumus sebagai berikut:

$$
Y=a+b_{1} X_{1}+b_{2} X_{2}+b_{3} X_{3}+e i
$$

Ada dua uji statistik yang digunakan dalam penelitian ini yaitu uji $t$ dan uji F. Uji t digunakan untuk mengetahui ada atau tidaknya pengaruh status sosial ekonomi $\left(\mathrm{X}_{1}\right)$, motivasi belajar $\left(\mathrm{X}_{2}\right)$, disiplin belajar $\left(\mathrm{X}_{3}\right)$ secara parsial pada prestasi belajar (Y). Uji $\mathrm{F}$ digunakan untuk mengetahui ada atau tidaknya pengaruh status sosial ekonomi $\left(\mathrm{X}_{1}\right)$, motivasi belajar $\left(\mathrm{X}_{2}\right)$, disiplin belajar $\left(\mathrm{X}_{3}\right)$ secara bersama-sama pada prestasi belajar (Y).

\section{HASIL PENELITIAN DAN PEMBAHASAN}

\section{Hasil Penelitian}

1. Deskriptif Variabel

a. Status Sosial Ekonomi

Berdasarkan jawaban responden untuk variabel status sosial ekonomi siswa di SMK Barunawati Surabaya secara keseluruhan termasuk dalam kategori sedang Dengan tingkat pendidikan terakhir orang tua ratarata adalah SMA/SMK dan kedua orang tua bekerja. Hal ini sesuai dengan beberapa penelitian dimana ketika tingkat status sosial ekonomi suatu keluarga dalam keadaan stabil dan tercukupi maka ini akan berpengaruh terhadap prestasi anak-anaknya disekolah.

b. Motivasi Belajar

Berdasarkan jawaban responden untuk variabel motivasi belajar siswa ditemukan jika responden di SMK Barunawati Surabaya memiliki motivasi belajar yang baik. Skor rata-rata indikator motivasi belajar yang 
tinggi yaitu untuk indikator adanya penghargaan dalam kelas dan untuk skor terendah berasal dari indikator adanya lingkungan belajar yang kondusif, sehingga memungkinkan seorang siswa belajar dengan baik.

c. Disiplin Belajar

Berdasarkan jawaban responden untuk variabel disiplin belajar ditemukan jika responden di SMK Barunawati Surabaya memiliki disiplin belajar yang baik.skor rata-rata tertinggi didapat dari indikator perilaku kedisiplinan diluar kelas di lingkungan sekolah dan skor rata-rata terendah didapat dari indikator perilaku kedisplinan dirumah.

d. Prestasi Belajar

Dari hasil jawaban responden untuk variabel prestasi belajar siswa di SMK Barunawati Surabaya didapat jika seluruh responden mendapatkan prestasi diatas KKM (Kriteria Ketuntasan Minimum)

2. Uji Asumsi

Uji asumsi klasik meliputi uji normalitas, multikolinieritas, linieritas dan heteroskedastisitas. Berdasarkan hasil uji normalitas didapat nilai sebesar 0,532 dengan tingkat signifikansi sebesar 0,939. Tingkat signifikansi tersebut lebih dari $5 \%$ yang berarti residual mengikuti distribusi normal. Sehingga variabel status sosial ekonomi $\left(\mathrm{X}_{1}\right)$, motivasi belajar $\left(\mathrm{X}_{2}\right)$, disiplin belajar $\left(\mathrm{X}_{3}\right)$, dan prestasi belajar (Y) berdistribusi normal.

Sedangkan untuk uji multikolinieritas untuk nilai tolerance status sosial ekonomi $\left(\mathrm{X}_{1}\right)$ sebesar 0,451, motivasi belajar $\left(\mathrm{X}_{2}\right)$ sebesar 0,379, disiplin belajar $\left(\mathrm{X}_{3}\right)$ 0,352. Dan untuk nilai VIF status sosial ekonomi $\left(\mathrm{X}_{1}\right)$ sebesar 2,220, motivasi belajar $\left(\mathrm{X}_{2}\right)$ sebesar 2,637, dan disiplin belajar $\left(\mathrm{X}_{3}\right)$ sebesar 2,839. Hasil pengujian linieritas hubungan antara variabel status sosial ekonomi orang tua $\left(\mathrm{X}_{1}\right)$ terhadap prestasi belajar $(\mathrm{Y})$ diketahui bahwa uji $\mathrm{F}$ Deviation from linierity adalah sebesar 1,054 dengan nilai signifikansi lebih dari 5\% yaitu sebesar 0,407 (lampiran). Hal ini berarti hubungan antara status sosial ekonomi orang tua $\left(\mathrm{X}_{1}\right)$ dengan prestasi belajar $(\mathrm{Y})$ adalah linier.

Untuk uji linieritas didapat hasil jika hubungan antara variabel motivasi belajar $\left(\mathrm{X}_{2}\right)$ terhadap prestasi belajar $(\mathrm{Y})$ diketahui bahwa uji $\mathrm{F}$ Deviation from linierity adalah sebesar 1,120 dengan nilai signifikansi lebih dari 5\% yaitu sebesar 0,360 (lampiran). Hal ini berarti hubungan antara motivasi belajar $\left(\mathrm{X}_{2}\right)$ dengan prestasi belajar $(\mathrm{Y})$ adalah linier. Hasil pengujian linieritas hubungan antara variabel disiplin belajar $\left(\mathrm{X}_{3}\right)$ terhadap prestasi belajar (Y) diketahui bahwa uji $\mathrm{F}$ Deviation from linierity adalah sebesar 1,217 dengan nilai signifikansi lebih dari 5\% yaitu sebesar 0,285. Hal ini berarti hubungan antara disiplin belajar $\left(\mathrm{X}_{3}\right)$ dengan prestasi belajar $(\mathrm{Y})$ adalah linier.

Sedangkan untuk hasil uji heteroskedastisitas menunjukkan jika nilai signifikansi yang dihasilkan oleh variabel status sosial ekonomi $\left(\mathrm{X}_{1}\right)$, motivasi belajar $\left(\mathrm{X}_{2}\right)$, disiplin belajar $\left(\mathrm{X}_{3}\right)$ melebihi alpha $(\alpha)$ yang ditentukan yaitu $5 \%$ sehingga antara variabel tidak terjadi heteroskedastisitas.

3. Uji Persyaratan Analisis

a. Persamaaan Regresi Linier Berganda

Adapun hasil pengolahan data dengan metode regresi linier berganda sebagai berikut:

$$
Y=75,026+0,357 X_{1}+0,175 X_{2}+0,200 X_{3}+e
$$


Dari persamaan regresi diatas menjelaskan bahwa:

1) Konstanta (a) yang dihasilkan sebesar 75,026 hal ini menunjukkan bahwa besarnya prestasi belajar siswa adalah 75,026 jika variabel status sosial ekonomi orang tua, motivasi belajar,disiplin belajar dianggap nol atau ditiadakan maka besarnya prestasi belajar (Y) sebesar 75,026.

2) Koefisien regresi pada variabel status sosial ekonomi orang tua adalah positif yaitu sebesar 0,357 artinya jika variabel status sosial ekonomi orang tua $\left(\mathrm{X}_{1}\right)$ naik satu satuan maka variabel prestasi belajar (Y) akan naik sebesar 0,357 satuan dengan asumsi bahwa variabel yang lain (motivasi belajar dan disiplin belajar) adalah konstan.

3) Koefisien regresi pada variabel motivasi belajar adalah positif yaitu sebesar 0,175 artinya jika variabel motivasi belajar $\left(\mathrm{X}_{2}\right)$ naik satu satuan maka variabel prestasi belajar (Y) akan naik sebesar 0,175 satuan dengan asumsi bahwa variabel yang lain (status sosial ekonomi orang tua dan disiplin belajar) adalah konstan.

4) Koefisien regresi pada variabel disiplin belajar adalah positif yaitu sebesar 0,200 artinya jika variabel disiplin belajar $\left(\mathrm{X}_{3}\right)$ naik satu satuan maka variabel prestasi belajar (Y) akan naik sebesar 0,200 satuan dengan asumsi bahwa variabel yang lain (status sosial ekonomi orang tua dan motivasi belajar) adalah konstan.

b. Uji t (Parsial)

Uji t digunakan untuk megetahui pengaruh status sosial ekonomi, motivasi belajar dan disiplin belajar secara parsial terhadap prestasi belajar. Adapun hasil uji t sebagai berikut:

Tabel 1. Hasil Uji t

\begin{tabular}{|l|l|c|c|c|}
\hline \multicolumn{1}{|c|}{ Variabel } & t hitung & $\begin{array}{c}\text { Tingkat } \\
\text { Signifikansi }\end{array}$ & $\begin{array}{c}\mathrm{r} \\
\text { parsial }\end{array}$ & $\begin{array}{c}\mathrm{r}^{2} \\
\text { parsial }\end{array}$ \\
\hline $\begin{array}{l}\text { Status Sosial Ekonomi } \\
\text { Orang Tua }\left(\mathrm{X}_{1}\right)\end{array}$ & 5,280 & 0,000 & 0,276 & 0,07618 \\
Motivasi Belajar $\left(\mathrm{X}_{2}\right)$ & 2,646 & 0,010 & 0,138 & 0,01904 \\
Disiplin Belajar $\left(\mathrm{X}_{3}\right)$ & 3,966 & 0,000 & 0,207 & 0,04285 \\
\hline
\end{tabular}

(Sumber : data diolah, 2014)

Penjelasan tabel di atas adalah:

Nilai t hitung pada variabel status sosial ekonomi orang tua $\left(\mathrm{X}_{1}\right)$ sebesar 5,280 dengan tingkat signifikan kurang dari 5\% yaitu 0,000. Hal ini berarti bahwa status sosial ekonomi orang tua $\left(\mathrm{X}_{1}\right)$ secara parsial berpengaruh secara signifikan terhadap prestasi belajar (Y). Besarnya pengaruh status sosial ekonomi orang tua $\left(\mathrm{X}_{1}\right)$ terhadap prestasi belajar $(\mathrm{Y})$ adalah $7,61 \%$.

Nilai t hitung pada variabel motivasi belajar $\left(\mathrm{X}_{2}\right)$ sebesar 3,966 dengan tingkat signifikan kurang dari 5\% yaitu 0,010. Hal ini berarti bahwa motivasi belajar $\left(\mathrm{X}_{2}\right)$ secara parsial berpengaruh secara signifikan terhadap prestasi belajar $(\mathrm{Y})$. Besarnya pengaruh motivasi belajar $\left(\mathrm{X}_{2}\right)$ terhadap prestasi belajar (Y) adalah 1,90\%. 
Nilai t hitung pada variabel disiplin belajar $\left(\mathrm{X}_{3}\right)$ sebesar 3,966 dengan tingkat signifikan kurang dari $5 \%$ yaitu 0,000 . Hal ini berarti bahwa disiplin belajar $\left(\mathrm{X}_{3}\right)$ secara parsial berpengaruh secara signifikan terhadap prestasi belajar $(\mathrm{Y})$. Besarnya pengaruh disiplin belajar $\left(\mathrm{X}_{3}\right)$ terhadap prestasi belajar (Y) adalah 4,28\%.

Hasil tersebut diatas menunjukkan bahwa variabel status sosial ekonomi orang tua lebih dominan pengaruhnya terhadap prestasi belajar siswa dibandingkan motivasi belajar dan disiplin belajar.

c. Uji F dan Nilai Koefisien Determinasi

Uji $\mathrm{F}$ digunakan untuk mengetahui apakh variabel status sosial ekonomi $\left(\mathrm{X}_{1}\right)$, motivasi belajar $\left(\mathrm{X}_{2}\right)$ dan disiplin belajar $\left(\mathrm{X}_{3}\right)$ secara bersama-sama berpengaruh secara signifikan terhadap prestasi belajar (Y). Adapun hasil uji $\mathrm{F}$ adalah sebagai berikut:

Tabel 2. Hasil Uji F

\begin{tabular}{|l|l|l|l|l|l|}
\hline \multicolumn{1}{|c|}{ Model } & Sum of Squares & f & Mean Square & F & Sig. \\
\hline Regression & 320.858 & & 106.953 & 96.420 & $.000^{\mathrm{a}}$ \\
Residual & 86.520 & 78 & 1.109 & & \\
Total & 407.378 & 1 & & & \\
\hline
\end{tabular}

a. Predictors: (Constant), DB, SSE, MB

b. Dependent Variable: PB

(Sumber : data diolah, 2014)

Dalam tabel diatas terlihat nilai f hitung yang dihasilkan adalah 96,420 dengan nilai signifikansi 0,000 kurang dari 0,05. Sehingga dapat disimpulkan pengaruh status sosial ekonomi, motivasi belajar dan disiplin belajar secara simultan berpengaruh signifikan terhadap prestasi belajar. Berarti H0 ditolak dan Ha diterima. Besarnya pengaruh pengaruh status sosial ekonomi, motivasi belajar dan disiplin belajar secara simultan terhadap prestasi belajar dapat dilihat dari Adjusted R-square yaitu:

Tabel 3. Model Summary

\begin{tabular}{|r|r|r|r|r|}
\hline Model & R & R Square & Adjusted R Square & \multicolumn{2}{|c|}{$\begin{array}{c}\text { Std. Error of the } \\
\text { Estimate }\end{array}$} \\
\hline 1 & $.887^{\mathrm{a}}$ & .788 & .779 & 1.053 \\
\hline
\end{tabular}

(Sumber : data diolah, 2014)

Nilai Adjusted R-Square yang dihasilkan sebesar 0,779 menunjukkan bahwa prestasi belajar dipengaruhi oleh status sosial ekonomi, motivasi belajar dan disiplin belajar sebesar 77,9\% sedangkan $22,1 \%$ dipengaruhi oleh faktor-faktor yang tidak dijelaskan dalam penelitian ini.

\section{Pembahasan}

1. Pengaruh Status Sosial Ekonomi Terhadap Prestasi Belajar

Dalam penelitian ini diperoleh hasil bahwa Status Sosial Ekonomi $\left(\mathrm{X}_{1}\right)$ secara parsial berpengaruh signifikan terhadap Prestasi Belajar (Y). Hal ini didasarkan pada hasil uji t yaitu nilai t hitungnya lebih besar yaitu sebesar 5,280 dan tingkat signifikansinya $5 \%$ yaitu 0,000 . Hal ini menunjukkan bahwa semakin tinggi status sosial ekonomi orang tua siswa maka semakin 
tinggi prestasi belajar siswa kelas XI di SMK Barunawati Surabaya. Adapun pengaruh status sosial ekonomi $\left(\mathrm{X}_{1}\right)$ terhadap Prestasi Belajar (Y) adalah sebesar 7,61\%.

Hal ini sesuai dengan penelitian Pangaribuan (1996) terhadap siswa SMA di Sulawesi Selatan menunujukkan bahwa terdapat perbedaan rata-rata skor siswa menurut jenis pekerjaan orang tua dalam hal inteligensi dan kemampuan membangun model dalam fisika. Jenis pekerjaan orang tua siswa diklasifikasi atas pegawai negeri, pengusaha dan petani

Hasil ini sesuai dengan penelitian Tirtarahardja (2005) mengemukakan hasil Thorndike antara lain menyimpulkan bahwa siswa yang berasal dari lingkungan keluarga dengan SSE yang tinggi, mencapai prestasi belajar lebih tinggi dibandingkan dengan siswa-siswa yang berasal dari lingkungan keluarga menengah dan rendah.

Hasil penelitian ini sejalan dengan penelitian sebelumnya yang dilakukan oleh Purwati (2011) yang menyimpulkan jika prestasi belajar ekonomi sangat memberikan kontribusi terhadap besarnya pengaruh status sosial ekonomi orang tua terhadap perilaku konsumsi siswa dan besarnya pengaruh persepsi siswa atau lingkungannya terhadap perilaku konsumsi siswa.

Lebih lanjut dalam penelitian Saifi (2011) yang menyatakan bahwa status sosial ekonomi yang stabil mencerminkan sebuah keluarga dalam pencapaian akademik dalam banyak cara. Hal ini juga menyimpulkan bahwa pendidikan orang tua penting dalam pencapaian pendidikan anak-anak mereka. Teknologi informasi dan fasilitas lainnya meningkatkan kinerja siswa dan mereka melakukannya dengan baik disekolah-sekolah. Akhirnya dibuktikan dengan hasil bahwa bahwa status sosial yang stabil dari sebuah keluarga membawa kenyamanan, sikap positif dan lingkunganyang sehat yang mengarah ke prestasi akademik yang tinggi sebagai bagian dari siswa.

Hasil penelitian tersebut selaras dengan penelitian yang dilakukan oleh Widodo (2007) menyatakan bahwa latar belakang pendidikan atau status sosial ekonomi orang tua berpengaruh secara signifikan terhadap prestasi siswa secara simultan maupun secara parsial dengan ditambah beberapa variabel lainnya.

Hasil peneltian ini sesuai dengan peneltian yang dilakukan oleh Eryanto (2013) dimana terdapat pengaruh yang signifikan antara tingkat pendidikan orang tua dan tingkat pendapatan orang tua terhadap prestasi akademik pada mahasiswa Fakultas Ekonomi Universitas Negeri Jakarta.

Hasil penelitian ini sesuai dengan Yanti (2006) Tingkat pendidikan orang tua khususnya ibu sangat erat hubungannya dengan prestasi anak dalam pelajaran matematika, karena itu dengan tingkat pendidikan yang tinggi orang tua dapat memberikan bantuan jika anaknya mendapat kesulitan dalam pelajaran matematika di luar sekolah.

Temuan di lapangan status sosial orang tua yang dapat dilihat dari pendapatan, pendidikan serta pekerjaan orang tua responden dapat di artikan jika pendapatan orang tua responden berada pada kategori berpendapatan sedang. Dengan tingkat pendidikan terakhir orang tua rata-rata adalah SMA/SMK dan okedua orang tua bekerja. Hal ini sesuai dengan beberapa penelitian di atas dimana ketika tingkat status sosial ekonomi suatu keluarga 
dalam keadaan stabil dan tercukupi maka ini akan berpengaruh terhadap prestasi anak-anaknya diskolah. Dengan kata lain status sosial ekonomi ini akan berpengaruh terhadap dukungan orang tua berupa fasilitas-fasilitas yang akan anak mereka gunakan dalam proses belajar mengajar.

Standart tinggi rendahnya status sosial ekonomi dapat diukur berdasarkan tingkat Upah Minimum Regional (UMR) didaerah tersebut. Standart tinggi rendahnya status sosial ekonomi dapat diukur berdasarkan penggolongan yang telah ditetapkan oleh Badan Pusata Statistik tahun (2004) dimana kategori pendapatan tinggi jika pendapatan rata-rata $\geq$ Rp. 2.500.000,$\leq$ Rp. 3.500.000,- /bulan. Selain itu standart tinggi rendahnya status sosial ekonomi dapat diukur tingkat Upah Minimum Regional (UMR) didaerah tersebut. Dimana kategori pendapatan tinggi jika pendapatan orang tua diatas UMR yang berlaku didaerah tersebut. Karena penelitian ini diadakan di kota Surabaya maka akan disesuaikan dengan UMR yang berlaku di Surabaya tahun 2014 yang telah ditetapkan melalui surat keputusan daerah tahun 2013 yaitu berkisar Rp 2.200.000 rupiah.

Dari hasil analisis data, telah terbukti bahwa terdapat pengaruh yang signifikan antara status sosial ekonomi orang tua dengan prestasi belajar siswa. Hal ini sesuai dengan teori dan penelitian yang telah dilakukan sebelumnya yang menyebutkan bahwa semakin tinggi status sosial ekonomi orang tua, maka semakin tinggi prestasi belajar siswa.

2. Pengaruh Motivasi Belajar Terhadap Prestasi Belajar

Dalam penelitian ini diperoleh hasil bahwa Motivasi Belajar $\left(\mathrm{X}_{2}\right)$ secara parsial berpengaruh signifikan terhadap Prestasi Belajar (Y). Hal ini didasarkan pada hasil uji t yaitu nilai t hitungnya lebih besar yaitu sebesar 2,646 dan tingkat signifikansinya $5 \%$ yaitu 0,010 . Hal ini menunjukkan bahwa semakin tinggi status sosial ekonomi orang tua siswa maka semakin tinggi prestasi belajar siswa kelas XI di SMK Barunawati Surabaya. Adapun pengaruh Motivasi Belajar $\left(\mathrm{X}_{2}\right)$ terhadap Prestasi Belajar $(\mathrm{Y})$ adalah sebesar $1,90 \%$.

Hal ini sesuai dengan penelitian Hulinggi (2007) yang menunjukkan jika terdapat hubungan positif antara motivasi dan prestasi belajar. Dan juga berdasarkan pada penelitian Wiyani (2013) terdapat pengaruh yang signifikan positif antara motivasi terhadap prestasi belajar.

Penelitian lain yang mendukung adalah penelitian dari Syarafuddin (2010) dengan judul hubungan antara lingkungan belajar, dukungan orang tua dan motvasi belajar dengan prestasi belajar siswa di SMA negeri di kabupaten Lombok Timur. Dimana dikemukakan jika terdapat hubungan yang positif dan signifikan antara motivasi belajar siswa dengan prestasi belajar siswa di SMA Negeri di kabupaten Lombok Timur.

Dari temuan penelitian didapat jika responden memiliki hasrat dan keinginan berhasil. Hal ini dapat dilihat dari jumlah respoden yang memilih ya lebih banyak ya untuk pertanyaan mengenai keinginan memperoleh nilai yang leih baik dalam semua mata pelajaran, mempunyai hasrat untuk meningkatkan pertumbuhan atau perkembangan pribadi, dan mempunyai hasrat untuk menerima pujian dari orang tua. Untuk indikator lain yaitu adanya dorongan dan kebutuhan dalam belajar responden juga menjawab ya 
lebih banyak terutama untuk item pertanyaan siswa terdorong untuk menjadi siswa terdidik. Hal ini menunjukkan jika responden siswa terdorong untuk menjadi siswa yang terdidik dan berpengalaman.

Selain itu untuk indikator adanya harapan dan cita-cita masa depan responden menjawab ya untuk pertanyaan siswa berkeinginan untuk berprestasi sehingga tercapai harapan atau cita-citanya. Ini menjelaskan jika siswa tetap mempunyai keinginan yang kuat untuk berprestasi sehingga bias mencapai semua cita-citanya. Untuk indikator adanya penghargaan dalam kelas dapat dijelaskan jika sebagian besar responden mendapatkan nilai mayta pelajaran di atas KKM (Kriteria Ketuntasan Minimal) untuk beberapa mata pelajaran produktif. Untuk indikator adanya kegiatan yang menarik dalam belajar responden beberapa siswa tertarik mengikuti kegiatan pembelajaran sehingga membuat responden selalu memperhatikan guru saat menjelaskan.

Namun di lapangan juga ditemui jika lingkungan yang kurang kondusif juga mempengaruhi motivasi belajar siswa. Terutama mengenai fasilitasfasilitas yang disediakan sekolah misalkan jumlah komputer yang lebih sedikit jika dibandingkan dengan jumlah siswanya. Selain itu penataan ruangan juga dirasakan siswa belum maksimal sehingga tidak mendukung kegiatan pembelajaran siswa.

Dari hasil analisis data, telah terbukti jika ada pengaruh yang signifikan antara motivasi belajar dengan prestasi belajar siswa. Dapat dikatakan jika motivasi belajar tinggi maka prestasi belajar yang didapat juga akan tinggi, dan sebaliknya jika motivasi belajar rendah maka prestasi belajar yang didapatkan juga rendah. Hal ini sesuai dengan teori dan penelitian-penelitian terdahulu.

3. Pengaruh Disiplin Belajar Terhadap Prestasi Belajar

Dalam penelitian ini diperoleh hasil bahwa Disiplin Belajar $\left(\mathrm{X}_{3}\right)$ secara parsial berpengaruh signifikan terhadap Prestasi Belajar (Y). Hal ini didasarkan pada hasil uji t yaitu nilai t hitungnya lebih besar yaitu sebesar 3,966 dan tingkat signifikansinya $5 \%$ yaitu 0,000 . Hal ini menunjukkan bahwa semakin tinggi status sosial ekonomi orang tua siswa maka semakin tinggi prestasi belajar siswa kelas XI di SMK Barunawati Surabaya. Adapun pengaruh Motivasi Belajar $\left(\mathrm{X}_{2}\right)$ terhadap Prestasi Belajar (Y) adalah sebesar $4,28 \%$.

Hasil tersebut sesuai dengan penelitian yang dilakukan oleh Setyowati (dalam Tomo, 2008) menyatakan belajar harus disiplin, karena disiplin adalah kunci sukses. Diungkapkan pula untuk mencapai prestasi belajar maksimal diperlukan sikap mental siswa dalam mengarahkan seluruh kegiatan belajarnya. Siswa yang ingin prestasi belajarnya tinggi harus mempunyai disiplin belajar yang tinggi. Hal ini disebabkan karena disiplin yang tinggi membuat siswa senantiasa mempunyai kesediaan, kegairahan dan tanggung jawab dalam belajar. Tanpa sikap ini, siswa cenderung tidak mampu mengatasi berbagai hambatan dan kesulitan dalam belajar.

Dari hasil temuan penelitian didapat jika pada indikator perilaku kedisplinan dalam kelas mayoritas responden selalu masuk tepat waktu, berdoa sebelum memulai pelajaran, berdoa sebelum mengakhiri pelajaran hal ini sesuai dengan data yang peneliti dapat dar BK (Bimbingan Konseling) 
jika responden terbiasa disiplin disekolah dengan mengikuti semua peraturan yang telah ditetapkan sekolah terutama tidak terlambat ke datang ke sekolah. Selain itu untuk indikator perilaku kedisplinan diluar kelas mayoritas responden menjawab ya dengan beberapa kategori pertanyaan misalkan siswa bersikap sopan santun dan menghormati sesama pelajar, pegawai dan petgas baik di dalam sekolah maupun di luar sekolah, siswa patuh terhadap petunjuk guru dan siswa tidak pernah meninggalkan kelas sekolah kecuali mendapat ijin khusus dari guru kelas. Ini sesuai dengan kenyataan dilapangan dimana setaiap kali siswa akan meninggalkan kelas ataupun sekolah maka siswa harus meminta surat ijin kepada guru BK yang ditanda tangani oleh guru kelas. Namun untuk item pertanyaan Siswa mengikuti upacara dengan tertib dan siswa membuang sampah pada tempat sampah responden mayoritas menjawab tidak. Mengenai pertanyaan pertama memang di akui siswa jika di sekolah jarang sekali mengadakan upacara kecuali hari-hari tertentu.

Untuk indikator terakhir yaitu perilaku kedisplinan dirumah jawaban responden menjawab tidak untuk sebagian pertanyaan terutama untuk item soal siswa bangun tepat waktu dan siswa mengerjakan PR yang telah diberikan oleh guru di sekolah. Hal in seharusnya yang membimbing adalah orang tua karena jika siswa hanya ditekan untuk disiplin disekolah maka akan sia-sia saja jika tidak diikuti dengan disiplin dirumah. Jika responden terbiasa disiplin disekolah dengan mengikuti semua peraturan yang telah ditetapkan sekolah, misalkan menggunakan atribut yang disediakan sekolah, tidak terlambat kesekolah dan lain-lain. Namun kenyataannya kebanyakan responden tidak biasa menerapkan kebiasaan disiplinnya di rumah. Ini terjadi karena beberapa kemungkinan, bias dikarenakan sikap orang tua yang kurang menerapkan disiplin dirumah sehingga responden juga terbiasa untuk tidak lagidisiplin dalam belajar dan melakukan hal lain yang akan mendukung sikap disiplin mereka disekolah.

Dari hasil analisis data, telah terbukti jika ada pengaruh yang signifikan antara disiplin belajar dengan prestasi belajar siswa. Dapat dikatakan jika disiplin belajar tinggi maka prestasi belajar yang didapat juga akan tinggi, dan sebaliknya jika disiplin belajar rendah maka prestasi belajar yang didapatkan juga rendah. Hal ini sesuai dengan teori dan penelitian-penelitian terdahulu. Dan dalam penelitian ini yang paling tinggi adalah untuk indikator disiplin belajar diluar kelas didalam sekolah.

4. Pengaruh Status Sosial Ekonomi, Motivasi Belajar, dan Disiplin Belajar Terhadap Prestasi Belajar

Berdasarkan hasil uji secara simultan menunjukkan bahwa status sosial ekonomi, motivasi belajar, dan disiplin belajar terhadap prestasi belajar berpengaruh secara signifikan terhadap prestasi belajar siswa. Hal ini didasarkan pada hasil penelitian yang dapat kita lihat dari $\mathrm{F}$ hitung sebesar 96,420 dengan nilai signifikansi 0,000 kurang dai 5\% sehingga dapat disimpulkan bahwa status sosial ekonomi $\left(\mathrm{X}_{1}\right)$, motivasi belajar $\left(\mathrm{X}_{2}\right)$, dan disiplin belajar $\left(\mathrm{X}_{3}\right)$ terhadap prestasi belajar $(\mathrm{Y})$ berpengaruh secara signifikan terhadap prestasi belajar siswa. Besarnya pengaruh status sosial ekonomi $\left(\mathrm{X}_{1}\right)$, motivasi belajar $\left(\mathrm{X}_{2}\right)$, dan disiplin belajar $\left(\mathrm{X}_{3}\right)$ terhadap prestasi belajar (Y) 77,9\% sedangkan sebesar 22,1\% dipengaruhi oleh faktor- 
faktor lain, selain variabel status sosial ekonomi, motivasi belajar, dan disiplin belajar.

Penelitian lain yang mendukung yaitu penelitian oleh Syamsuddin (2002) dengan judul hubungan disiplin belajar dan motivasi belajar dengan prestasi belajar di SLTP negeri di kabupaten Malang. Hasil penelitian ini mengemukakan jika terdapat hubungan langsung positif disiplin belajar dengan prestasi belajar, terdapat berhubungan langsung positif motivasi belajar dengan prestasi belajar. Hasil penelitian juga menyimpulkan jika terdapat hubungan yang positif antara disiplin belajar siswa dan motivasi belajar dengan prestasi belajar.

Selanjutnya penelitian ini juga dikuatkan dengan penelitian yang dilakukan oleh Tomo (2008) dengan judul hubungan antara sikap, motivasi, disiplin belajar dan prestasi belajar mahasiswi D-II PGSD prajabatan FKIP Universitas Pattimura.. Hasil penelitian ini mengemukakan jika terdapat hubungan langsung positif motivasi belajar dengan prestasi belajar, terdapat berhubungan langsung positif disiplin belajar dengan prestasi belajar. Hasil penelitian juga menyimpulkan jika terdapat hubungan yang positif antara motivasi belajar siswa dan disiplin belajar dengan prestasi belajar.

Fakta yang ditemukan dilapangan menunjukkan bahwa status sosial ekonomi orang tua tinggi dalam pengertian pendapatan orang tua mereka rata-rata di atas UMR (Upah Minimum Regional) yang berlaku tahun 2014 di Surabaya yaitu Rp. 2.200.000,- dan hal ini hampir sama dengan kategori pendapatan tinggi berdasarkan Badan Pusat Statistik (2004) yaitu jika pendapatan rata-rata $\geq$ Rp. $2.500 .000,-\leq \mathrm{Rp} .3 .500 .000$,- /bulan dengan latar pendidikan rata-rata SMA/SMK dan rata-rata orang tua bekerja. Sedangkan responden termotivasi untuk meningkatkan prestasi belajar mereka dikarenakan dukungan dari orang tua dan sekolah berupa penyediaan fasilitas-fasilitas yang mendukung proses kegiatan belajar mengajar. Kedisiplinan yang diterapkan disekolah ikut serta mendukung peningkatan prestasi mereka disekolah. Hal ini dapat dilihat dari beberapa jawaban responden yang berkaitan dnegan disiplin sekolah mendapat skor yang tinggi untuk jawaban ya atau dapat diartikan mereka mematuhi peraturan yang dterapkan disekolah.

Dari penelitian tentang status sosial ekonomi, motivasi belajar, disiplin belajar berpengaruh terhadap prestasi belajar di atas dapat dijadikan landasan bahwa variabel status sosial ekonomi, motivasi belajar, disiplin belajar berpengaruh secara signifikan terhadap prestasi belajar.

\section{KESIMPULAN}

Berdasarkan pembahasan dan hasil analisis data yang dilakukan dalam penelitian ini dapat disimpulkan sebagai berikut:

1. Terdapat pengaruh signifikan status sosial ekonomi terhadap prestasi belajar di SMK Barunawati Surabaya. Hal ini berarti semakin tinggi status sosial ekonomi orang tua maka akan semakin tinggi pula prestasi belajar siswa.

2. Terdapat pengaruh signifikan motivasi belajar terhadap prestasi belajar di SMK Barunawati Surabaya. Hal ini berarti semakin tinggi motivasi belajar maka akan semakin tinggi pula prestasi belajar siswa. Motivasi tinggi dapat 
dilihat dari dorongan dan keinginan responden untuk mendapatkan pengetahuan lebih baik lagi dengan cara mengikuti pembelajaran dengan baik. Selain itu motivasi dari sekolah yang berhubungan dengan menyediaan fasilitas yang akan mendukung motivasi belajar siswa juga ikut serta mempengaruhi.

3. Terdapat pengaruh signifikan disiplin belajar terhadap prestasi belajar di SMK Barunawati Surabaya. Hal ini berarti semakin tinggi disiplin belajar maka akan semakin tinggi pula prestasi belajar siswa. Hal ini dapat dilihat dari disiplin siswa untuk mematuhi peraturan yang berlaku disekolah dan dirumah.

4. Terdapat pengaruh signifikan status sosial ekonomi orang tua, motivasi belajar, disiplin belajar secara bersama-sama terhadap prestasi belajar di SMK Barunawati Surabaya. Hal ini berarti semakin tinggi status sosial ekonomi orang tua, motivasi belajar dan disiplin belajar maka akan semakin tinggi pula prestasi belajar siswa di SMK Barunawati Surabaya.

\section{DAFTAR RUJUKAN}

Azwar, Saifuddin. 2003. Tes prestasi: Fungsi dan pengembangan pengukuran prestasi belajar. Yogyakarta: Pustaka Pelajar Offset

Burden, P. R, \& Byrd, D. M. 2014. Method for Effective Teaching (4 ${ }^{\text {th }}$ Ed.). Boston: Allyn and Bacon

Cahyono, Purwo. 2013. Pengaruh Budaya Organisai dan Status Sosial Ekonomi Pada Kompetensi Profesional Guru di SMA Negeri 13 Surabaya. Tesis. Jurnal Ekonomi Pendidikan dan Kewirausahaan . Vol. 1. No. 2 Oktober. Hal. $174-185$.

Eryanto, Henry \& Darma Rika S. 2013. Pengaruh Modal Budaya, Tingkat Pendidikan Orang Tua dan Tingkat Pendapatan Orang Tua Terhadap Prestasi Akademik Pada Mahasiswa Fakultas Ekonomi Universitas Negeri Jakarta. Jurnal Pendidikan Ekonomi dan Bisnis Vol.1 No.1 Maret 2013 ISNN: 2302 - 2663. Hal 49-59.

Hadiyanto, Herman. 2013. Pengaruh Pendidikan, Pekerjaan, Pendapatan Orang Tua terhadap Prestasi Belajar Pada Siswa SMA Negeri 15 Surabaya. Tesis. Universitas Negeri Surabaya.

Hasibuan, Malayu.S.P. 2001. Manajemen Dasar, Pengertian dan Masalah. Jakarta: PT. Bumi Aksara

Hulinggi, Sumarno. 2007. Hubungan antara supevisi pengawas sekolah, kepemimpinan kepala sekolah, perilaku mengajar guru, motivasi belajar siswa, dan pemanfaatan fasilitas belajar dengan prestasi belajar siswa SMA Negeri di Sulawesi Tengah. Disertasi. Program Studi Manajemen Pendidikan, Program Pascasarjana Universitas Negeri Malang.

Mujiono, Dimyati. 2006. Belajar dan Pembelajaran. Jakarta : PT Rineka Cipta.

Nasution, Syafrina dan Lemta Tarigan. 2013. Pengaruh Sosial Ekonomi Orang Tua terhadap Mnat Anak Melanjutkan Pendidikan ke Perguruan Tinggi (Studi Kasus Kelas XI Semester Genap di SMA Sinar Husni Medan Helventia Kabupaten Deli Serdang Tahun Pelajaran 2010/2011). Artikel Penelitian. Jurnal CITIZENSHIP Volume 00 Nomor 00 2013. Hal. 35- 52.

Ogunshola, Femi \& A.M Adewale. 2012. The Effects Of Parental SocioEconomic Status on Academic Performance of Student in Selected Schools in Edu Lga of Kwara State Nigeria. International Journal of Academic 
Research in Business and Social Sciences July 2012. Vol. 2 No. 7 ISSN: 2222-6990.

Pangaribuan, Firman. 1996. Hubungan Gaya Kognitif, Kemampuan Penalaran Formal, Status Sosial Ekonomi Orang tua dan Lingkungan Pendidikan Keluarga dengan Prestasi Belajar Matematika Siswa Kelas 1 SMU Negeri Kodya Pematang Siantar. Tesis. Institut Keguruan dan Ilmu Pendidikan Malang. Program Pascasarjana.

Purwati, Ana. 2011. Pengaruh Status Sosal Ekonomi Orang Tua, Persepsi Atas Lingkungan, dan Prestasi Belajar Ekonomi terhadap Perilaku Konsumsi. Tesis. Jurnal Ekonomi Bisnis. TH.16, No. . Hal. 11-16.

Saifi, Saifullah \& Tariq Mehmood. 2011. Effects Of Socioeconomic Status On Student Achievement. International Journal of Social Sciences and Education Volume: 1 Issue: 2 April 2011. Hal. 119-128

Schunk, Dale H., Paul R. Pintrich, dan Judith L. Meece (Eds). 2008. Motivation in Education: Theory, Research and Application, Third Edition. New Jersey: Pearson Educati. Inc.

Slameto. 2010. Belajar dan Faktor-Faktor yang mempengaruhinya. Jakarta: Rineka Cipta.

Syamsuddin. 2002. Hubungan Disiplin Belajar dan Motivasi Belajar dengan Prestasi Belajar Siswa SLTP Negeri di Kabupaten Malang. Tesis. Malang: Universitas Negeri Malang.

Syarafuddin, Muhammad. 2010. Hubungan Antara Lingkungan Belajar, Dukungan Orang Tua dan Motivasi Belajar dengan Prestasi Belajar Siswa SMA Negeri di Kabupaten Lombok Timur. Tesis. Malang: Universitas Negeri Malang.

Tirtarahardja, Umar. 2005. Pengantar Pendidikan Edisi Revisi. Jakarta: PT Rineka Cipta.

Tjundjing, S. 2001. Hubungan antara IQ, EQ, dan AQ dengan prestasi pendidikan pada siswa SMU. Anima, Indonesian Psichological Journal. Vol .17. No. 1. Hal 69-92.

Tomo, J. 2008. Hubungan Antara Sikap, Motivasi, Disiplin Belajar dan Prestasi Belajar Mahasiswa D-II PGSD Prajabatan FKIP Uiversitas Pattimura. Tesis. Malang: Universitas Negeri Malang.

Uno, Hamzah. 2008. Teori Motivasi dan Pengukurannya, Analisis di Bidang Pendidikan. Jakarta: PT Bumi Aksara.

Widodo, Heri. 2007. Pengaruh Hasil Praktek Kerja Industri (Prakerin), Motivasi Belajar, dan Latar Belakang Keluarga Siswa Terhadap Prestasi Belajar Siswa SMK Jurusan Listrik di Kendal. Tesis. Malang: Universitas Negeri Malang.

Wijani, Tri Ervina K. 2013. Pengaruh Konsep Kemandirian, Motivasi dan Lingkungan Belajar Pada Prestasi Belajar Ekonomi Siswa Kelas XI IPS SMA Negeri di Kabupaten Gresik. Jurnal Ekonomi Pendidikan dan Kewirausahaan. Vol. 1. No. 2 Oktober. Hal. 129-137.

Yanti, Teti Sofia dan Icih Sukarcih. 2006. Hubungan Antara Tingkat Pendidikan Orang Tua Dengan Prestasi Siswa Sekolah Dasar Dalam Mata Pelajaran Matematika Di Kecamatan Cicadas Kota Bandung. Mimbar Volume XXII No.2 April-Juni. 206-212. 